Article

\title{
Assessment of the Successes and Failures of Decentralized Energy Solutions and Implications for the Water-Energy-Food Security Nexus: Case Studies from Developing Countries
}

\author{
Dawit Diriba Guta ${ }^{1}$, Jose Jara ${ }^{2} \mathbb{D}$, Narayan Prasad Adhikari ${ }^{3}$, Qiu Chen ${ }^{2}$, Varun Gaur ${ }^{2}$ \\ and Alisher Mirzabaev ${ }^{2}$ * (D) \\ 1 Center for Environment and Development, College of Development Studies, Addis Ababa University, \\ Addis Ababa P.O.BOX 1176, Ethiopia; davdiriba@yahoo.com \\ 2 Center for Development Research (ZEF), University of Bonn, Bonn 53113, Germany; \\ jose.jara.a@gmail.com (J.J.); chen.qiusau@gmail.com (C.Q.); varungaur.engg@gmail.com (V.G.) \\ 3 Alternative Energy Promotion Centre (AEPC), Ministry of Population and Environment, Khumaltar, \\ Lalitpur G.P.O. Box: 14364 Kathmandu, Nepal; narayan.aepc@gmail.com \\ * Correspondence: almir@uni-bonn.de; Tel.: +49-228-731-915
}

Received: 30 March 2017; Accepted: 20 June 2017; Published: 30 June 2017

\begin{abstract}
Access to reliable and affordable energy is vital for sustainable development. In the off-grid areas of developing countries, decentralized energy solutions have received increasing attention due to their contributions to reducing poverty. However, most of the rural population in many developing countries still has little or no access to modern energy technologies. This paper assesses the factors that determine the successes and failures of decentralized energy solutions based on local harmonized case studies from heterogeneous contexts from Asia, sub-Saharan Africa, and South America. The case studies were analyzed through the coupled lenses of energy transition and the Water-Energy-Food Security (WEF) Nexus. The findings indicate that access to modern decentralized energy solutions has not resulted in complete energy transitions due to various tradeoffs with the other domains of the WEF Nexus. On the other hand, the case studies point at the potential for improvements in food security, incomes, health, the empowerment of women, and resource conservation when synergies between decentralized energy solutions and other components of the WEF Nexus are present.
\end{abstract}

Keywords: decentralized energy; Water-Energy-Food Security (WEF) Nexus

\section{Introduction}

Access to modern, affordable energy services, which encompass access to electricity and clean cooking technologies, is one of the necessary inputs for the achievement of Sustainable Development Goals (SDGs). Nowadays, over 1.3 billion people still lack access to electricity, and 2.6 billion people are without clean cooking technologies [1]. A lack of clean, affordable, and sustainable energy is linked with household and community welfare in multifaceted ways [2]. For example, many low income and off-grid households in developing countries rely on traditional biomass for their energy needs [3]. Several studies find that this is often associated with womens' drudgery, the withdrawal of children from school, health hazards from indoor air pollution, deforestation, soil erosion, and a loss of biodiversity and related negative impacts on ecology and food security (for example, a trade-off between food production and fuelwood collection in terms of family labor allocation) [4-9].

Despite recent improvements in electrification, and expanded access to more efficient cooking fuels in developing regions, energy access still remains a pressing problem [10], especially in the rural areas of developing countries [1]. In this context, decentralized energy solutions (DES) can significantly 
contribute towards universal access to modern energy services. However, the adoption of modern DES by rural households and communities in developing countries has mostly been constrained due to upfront costs, a lack of financing opportunities, and a lack of technical capabilities [11]. DES are local transformations of renewable resources (wind, solar radiation, biomass, and small hydropower) into electricity or thermal energy. Although DES could vary considerably in scale, the focus of this paper is on small scale DES used at the level of households and communities.

Attaining SDGs requires the availability of adequate energy beyond residential energy uses, including for the needs of community institutions such as health care centers, schools, and for operating water services, and telephone and internet communications. Nevertheless, a lack of modern energy services is only a part of the problem for the achievement of SDGs, since rural households and communities are also facing water and food security challenges. This, combined with exponential population growth and increasing pressures on natural resources, requires policy actions promoting a more efficient use of these scarce resources $[4,12,13]$. Hence, an improved understanding of DES within the framework of the Water-Energy-Food Security (WEF) Nexus can provide an innovative and more comprehensive insight into the role of modern energy services, and can lead to new solutions for sustainable development [5,12-14].

Although many studies have evaluated the successes and failures of DES, most of them have focused on isolated aspects and missed important interlinkages along the WEF Nexus' dimensions. Many studies have attempted to evaluate the performance of DES by focusing on a given community (geography), on a single energy technology, and only on "socio-economic", "socio-technologic", or "ecological technology" aspects [11,15]. Therefore, in the face of complicated challenges, to achieve positive impacts such as poverty reduction, the empowerment of women, enhanced food security, human and environmental health, and to satisfy long-term sustainability needs, DES should be perceived as an integral part of the WEF Nexus $[5,14,16]$. Yet, both the previous research, as well as policies and development interventions, have overlooked the critical links of DES in the WEF Nexus framework. These links need to be adequately integrated into energy policy designs to support rural development.

There are two gaps in the literature that served as the motivation for this study. First, so far there have been only a scant number of cross-country studies on the failures and successes of DES in developing countries. Second, DES is an important component of the WEF Nexus, but little is known about the barriers and incentives for DES in connection to the other components of the WEF Nexus.

Therefore, this paper seeks to answer two research questions. The first is: what are the water and food interlinkages of (selected) DES? The second is: what are the incentives and barriers for the successful adoption of DES under the WEF Nexus?

\section{Background}

\subsection{DES and the Water-Energy-Food Security Nexus}

It is widely recognized that the water, energy, and food sectors have strong interconnections and interdependencies [12]. To illustrate, energy is used in agricultural production for irrigation, water pumping, mechanized agriculture, and post-harvest processing and transportation [17]. The water and energy footprints of food production were found to be significant at all scales (locally, nationally, and globally) [18]. Besides, poor agricultural practices (leading to soil erosion or deforestation) were found to negatively affect the availability and quality of water resources [6,17]. Energy and food production activities also compete for land and water resources, which may, consequently, lead to food-fuel tradeoffs. At the same time, DES play an important role in water treatment and addressing clean water availability problems in the remote communities of developing countries. However, there are a number of challenges related to the use of modern DES, such as limited local capacity (for example, a lack of skilled labor), a lack of spare parts, high upfront costs, inappropriate designs, and other socio-economic factors [19]. Policy actions are required for jointly addressing the challenges of climate change, sustainable natural 
resource management, access to energy, and improving agricultural productivity [20], and to support investments in technologies for improving water productivity and agricultural energy use efficiency [19]. Therefore, a joint solution for exploiting the synergies and reducing the risks of trade-offs of DES within the WEF Nexus is necessary, as neglecting the interconnectedness of DES and the overall WEF Nexus may lead to suboptimal outcomes [21].

\subsection{Energy Transitions}

To understand the problem of the low diffusion of modern DES and their linkages with the WEF Nexus in developing countries, it is important to understand rural energy demand. In low income countries, most of the household energy consumption is thermal energy, with very little electricity consumption [22]. Thermal energy is necessary to fulfill very basic human needs (food, heat), while electricity access depends on rural households' income [23]. There are rich debates on the household energy transition concepts in the literature [4,5]. The major debate is on whether the energy transition process follows the energy ladder or the energy stacking. The energy ladder conceptualizes energy choice as a linear step-by-step transition process with increases in income, and assumes that energy users with rising incomes abandon the less efficient and cheaper traditional biomass and shift to intermediate energy sources (charcoal and coal); and then to modern, safer, and more efficient energy sources like electricity [24,25]. In contrast, the energy stacking states that energy consumers use multiple energy sources, and their choice is modulated by a multitude of socio-economic and cultural preferences beyond income [4,26-28]. A potential for an "energy leapfrogging "concept, involving a bypass of conventional energy and a leap directly to more efficient, safer, and environmentally friendlier energy technologies, was also discussed in the literature [29,30]. Energy technology "leapfrogging", however, appears to be very challenging because it needs a simultaneous institutional "leapfrogging" [26,29].

\subsection{Successes and Failures of DES in Energy Transition}

Energy supply in rural communities is complex, and is not a simple selection of a technology but also involves multiple criteria with a strong link to livelihoods [31]. The performance of DES depends on the political setting, socio-cultural traditions, cooperation among multiple stakeholders, and legal rules and regulations [15,32]. Community participation is a key factor that reduces bureaucracy and transaction costs [33]. Similar to other investments, community participation is believed to improve the long term sustainability of decentralized energy projects [34]. For instance, community participation and local knowledge were found to have a determining role for the success of decentralized energy projects in Bolivia [35], India [36], and Brazil [37].However, DES in developing countries are often initiated and established with assistances from outside (government, non-governmental or international donors and partners) [11,34], making them susceptible to uncertainty without the continued support of outsiders. Community-based approaches through empowering and creating local participation in the planning and execution of DES projects would enable direct control by local players in the monitoring and management of resources to improve the sustainability of investment decisions [38]. The community approach has been considered as a valid alternative to the government- and market-based provision of energy [39]. However, community-based energy investments also face complex barriers. In order to increase the stability and predictability of DES, institutional organizations should be established to facilitate discussions among different government levels' actors and enable communities to play a role [40]. Thus, structured legal rules and binding contracts are critical factors for the success of DES. On the other hand, DES can enhance local governance capacities, because decentralization increases the "space for local actors" [39].

Despite the economic benefits of decentralized energy, there is mixed evidence on its ecological sustainability. DES such as biogas, improved cook stoves, micro hydropower, and solar power were found to help rural communities in Nepal to reduce their carbon emissions [40]. In contrast, a study in Guizhou, China, on micro hydropower (MHP) evaluated the cost of the project and indicated 
that the eco-friendliness of the project remains highly contested due to the impact on the downstream drying up of the river, and recommended a cautious approach to maximize the benefits and mitigate negative ecological impacts [41].

In off-grid communities in developing countries, the conventional diesel electricity generation can be cost-effectively substituted by renewable sources $[42,43]$. Decentralized biomass energy in remote rural communities of Colombia was found to reduce the system's net cost and carbon emissions [43], because it reduces the transportation cost and supports sustainable local development. Extended payment schedules, low interest rates, and taxes improve household electricity affordability [44]. A lack of credit is one of the key determinants of the long-term sustainability of DES, and encompasses not only an upfront installation cost, but also the costs of operation and management of the projects over time. Small scale DES are often discriminated against by the capital markets. A cross-country study indicated that financing local energy technology development was constrained by a limited length and amount of funding [15]. Government and donor organizations play a crucial role in controlling the technological specifications and/or supporting project subsidies for installations [45]. Community-focused microfinance schemes for low income clients were found to help tackle the financial barriers [46].

\section{Conceptual Framework}

The conceptual framework guiding this study is depicted in Figure 1.The conceptual framework highlights the interconnectedness of DES within the WEF Nexus and links the energy transitions and the WEF Nexus at the household and community levels from DES perspectives.

DES are a means of energy provision for households and communities affecting the WEF Nexus, but also a tool for energy transition. The WEF Nexus, adoption of DES, and energy transition are affected by common contextual factors that could be broadly categorized as economic, social, environmental, technological, policy-related, and institutional. Economic factors refer to financial and market aspects, including resource scarcities and relative factors prices, which influence the adoption of DES, energy transition, and the externalities of the WEF Nexus' interactions. Social factors refer to cultural and social dimensions affecting energy and water use, food systems, their interactions, as well as people's knowledge of the use and perceptions of DES. For example, as highlighted earlier, community participation often plays a key role in DES adoption. Political and institutional factors encompass the regulatory and political, as well as institutional aspects. Environmental factors refer to biophysical factors, such as climate, agro-ecologies, and soils affecting DES, energy transition, and the WEF Nexus through shaping relative resource scarcities [11,15]. Such broad categorization also allows for the implicit inclusion of numerous specific factors such as access to markets, access to rural advisory services and credit, land tenure security, the existence or lack of property rights to water, etc. under these broad categories [47].These contextual factors were identified based on the reviewed literature. These contextual factors and their various interactions serve either as catalysts or barriers for DES adoption and energy transitions, and also shape the tradeoffs and synergies within the WEF Nexus, with significant impacts on the outcomes in terms of human and social wellbeing identified through food security, energy security, poverty reduction, environmental conservation, and the improvement of quality of life for rural households and communities. These outcome variables were selected to highlight the WEF Nexus' priorities, which seek to enhance food and energy security, environmental conservation through increased resource use efficiency, as well as the expected implications of energy transitions on poverty reduction and human health (e.g., through lower indoor air pollution). The relationships between DES, contextual factors, energy transition, and the WEF Nexus are, in most cases, expected to be endogenous, i.e., with multiple feedbacks; hence, they are depicted with two-sided arrows.

The proposed conceptual framework allows us to identify the links between the studied DES and the broader WEF Nexus and energy transition processes, helping us to understand their actual and potential implications on human and social wellbeing. 


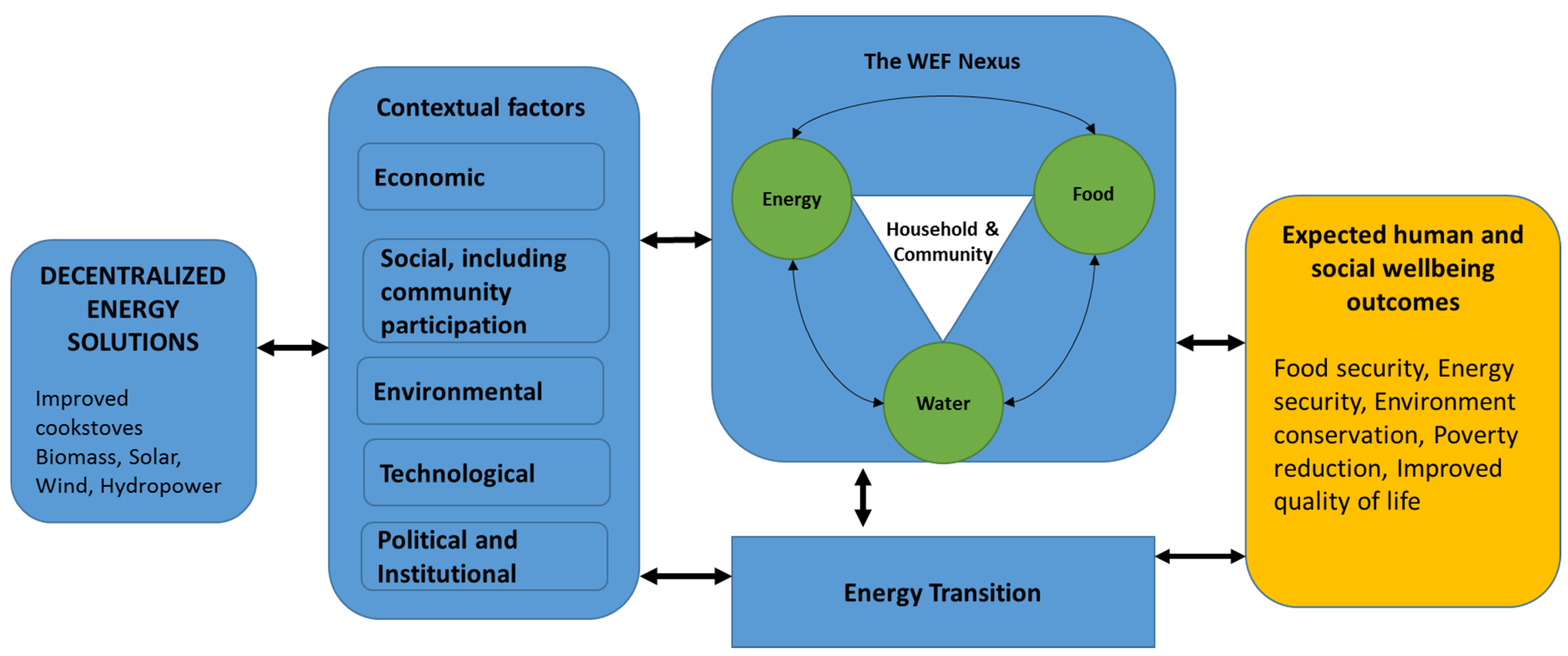

Figure 1. The conceptual framework. 


\section{Materials and Methods}

This paper employs a qualitative case study methodology [48] to study the complex interactions between DES, the WEF Nexus, and energy transitions within their contexts to understand the specific underlying factors behind successes and failures of DES, as well their impacts on the WEF Nexus and energy transition. Case studies are a widely practiced tool in policy studies because of their flexibility. Case studies are especially relevant when the studied phenomena are not easily separable from their contexts [48]. At the same time, the selection of case studies from heterogeneous settings and examining them using a standardized analytical framework can contribute to more generalizable insights when findings from these diverse settings point to similar conclusions. Therefore, the selection of the case studies in this paper was guided by the objective to learn from the heterogeneities of DES in different local contexts in developing countries. The selected locations represent different geographic, socio-economic, and institutional contexts from China, Ethiopia, Ecuador, India, and Nepal. As a result, they have different experiences of successes and failures, cover one or more rural energy use (electricity, cooking, heating), and various energy technologies (improved cook stove, bioenergy, hybrid technologies etc.). Hence, these case studies incorporated four major renewable energy sources: biomass, hydro, solar, and wind. Of the technologies, biogas and improved cook stove (ICS) are on the household level, whereas the micro-hydro, wind-solar hybrid, biomass gasifier, and jatropha oil expeller are managed at the community level.

While conducting the case studies, a wide variety of information and data sources were utilized. This included reviews, published research articles, project documents, and other secondary data, as well as our own empirical observations.

\section{Results}

\subsection{Case Study 1: Household Biogas Digester Project in Chunfeng Village in China}

Implementation: Chunfeng Village is located in the mountainous areas of Junlian County at the border of Sichuan Province and Yunnan Province. It covers an area of 347 ha, among which the area of arable land is 267 ha. There are 203 households with total population of 864 people [49]. People living there at one time depended heavily on firewood and coal for cooking. The direct combustion of these types of energy caused many serious consequences such as indoor air pollution and environmental damage. In order to improve rural living standards and to reduce the pollution from rural energy use, the Ministry of Agriculture (MOA) started the "Prosperous ecofarmyards "plan in 2000 [50]. As the "core instrument" of this plan, the household-based biogas digester construction project was promoted in Chunfeng Village from 2003 onward. By 2013, 136 biogas digesters had been built in Chunfeng Village. The penetration of biogas had been about $72 \%$ [51].

Description of technologies or products and services: In the process of the implementation of the household-based biogas digester construction project, the required size of the biogas digesters was found to be on average $8-10 \mathrm{~m}^{3}$ [51]. Fiberglass-Reinforced Plastic (FRP) dome cover digesters were promoted in Chunfeng Village. Compared with other types of digesters, the FRP digester can produce at least a third more biogas using the same amount of feedstock. Also, the household biogas digester project emphasizes a three-in-one ecological agriculture mode of "pig rising - biogas digester - orchard cultivation". The system consists of a sanitary toilet/livestock house (pig sty), a biogas digester (with stove in kitchen), and an orchard (field). The human and animal wastes are used as feedstock to produce biogas, which is then used as cooking fuel [51]. The biogas slurry and residues can be used as a fertilizer, while the anaerobic digestion effluents can be used to feed pigs in a mixture with fodders.

Barriers and enablers: In order to boost households' motivation to use biogas, subsidies were provided by central and local governments to the households in Chunfeng Village for building new domestic biogas digesters. Nevertheless, barriers hindering the further development of the household biogas project still exist. Too little attention has been given to the quality as opposed 
to quantity in the infrastructure's construction due to the overemphasis on low-cost construction, resulting in the short service life of the digesters and the stoves. A lack of sufficient knowledge and skills regarding effective operation and management as well as enough services for maintenance at a household level may cause the disuse of the digesters. In addition, the new biogas technologies cannot be applied in practice and popularized in bigger scales, due to a lack of matching policies and institutional arrangements.

WEF Nexus linkages: With respect to the effects of biogas use on water resources, the household biogas digester project not only mitigated the contamination of drinking water by human and animal fecal matter [50], but also reduced the pollution of local surface and ground water caused by using chemical fertilizers and pesticides [52]. Additionally, the use of biogas instead of firewood protects forests, and thus can help avoid damage to watersheds caused by deforestation and an excessive exploitation of forest resources [53]. On the other hand, the "three-in-one" mode changed the traditional agricultural production methods, promoting the development of a courtyard economy and the improvement of food production efficiency. It reduced the food production cost by decreasing households' expenditure on chemical fertilizers. The high-quality sludge-like organic fertilizers (i.e., anaerobic digestion residues and effluents) were applied to backyard orchards or nearby fields to produce more food without the pollution caused by the chemical elements [53]. Moreover, the use of biogas reduced the need for crops of straw and firewood, and therefore reduced the time spent on collecting and processing them, and thus freed household labor from the workload of biomass collection so it could be put to food production [54].

\subsection{Case Study 2: Improved Cook Stoves Experiences in Ecuador}

Implementation: In 2010, improved cook stoves (ICS) were distributed among 800 rural and isolated households in the highland region of the Ecuadorian Andes. This is the biggest experience documented in Ecuador so far on ICS distribution. This initiative was driven to tackle precarious and unhealthy cooking conditions, high rates of deforestation in the Andean communities, and to provide an alternative to the costly and often unavailable Liquid Petroleum Gas (LGP), which is the main subsidized source for cooking in Ecuador [55].

Description of technologies or products and services: The fixed ICS had two cooktops and a chimney, was built with adobe and bricks, and based on a certified model implemented in similar conditions in Peru [55]. After six months of their implementation, the impacts documented by [55] were: (i) an average reduction of wood consumption for cooking of $40 \%$ with a maximum value of $70 \%$; (ii) improvements in cooking conditions (i.e., better position to cook, less time for cooking, less risk for fire accidents, and physical modifications of kitchens including painting, shelves, household landfills, and eco-refrigerators); (iii) the initiation of healthy practices for cooking and eating (i.e., consumption of boiled water, animals out of the kitchen, wash hands before eating, and cleaning the kitchen and house); (iv) improved health conditions of women and children (i.e., less pain in the eyes, headaches, and throat pains); and (v) allowed for social gatherings in kitchens thanks to the warm temperature and cleanliness.

Barriers and enablers: ICS implementation and adoption was inhibited by multiple factors [55]: (i) low interest in ICS because of a strong bond to traditional cooking practices, and a belief that the present cooking situation was not burdening on health;(ii) influential people's distrust about the project's intentions because it was perceived to have hidden government strategies to increase the cost of LPG, previous bad experiences with ICS in neighboring communities, and husbands' mistrust strongly preventing wives' participation;(iii) a lack of local providers of ICS parts (hot plate) delayed the construction of ICS affecting again people's trust; and (iv) the difficult initial use of ICS led to higher wood consumption, more time required for cooking, and problems with smoke. To tackle these problems, different strategies and drivers were identified [55]: (i) a communication plan, the participation of local leaders (i.e., "guide mothers"), and installing pilot ICS in selected households to enhance the trustfulness and the project's acceptance, especially among husbands, 
which also ensured knowledge transfer on the maintenance and use of ICS;(ii) the participation of local and communal governments was key for funding access and project implementation;(iii) the success of ICS attracted new users; reinforcing the acceptance of and local demand for ICS;(iv) a local industry reinforced with strong government support and policies is required to scale up ICS in the region; and (v) further research on the ICS's design and application suitable for the Andean region is needed.

WEF Nexus linkages: The reduction of wood consumption has an impact on reducing deforestation, and therefore enhances water regulation [55], but further research work is required to quantify these effects in this specific case. Regarding energy links, cooking with ICS was slow and was not suitable during communal gatherings $[3,14,55]$. Thus, better ICS designs are needed to enable complete transition to modern energies. Regarding food security linkages, ICS adoption encouraged the construction and use of other technologies (eco-fridge, household landfill, and shelves), which improved food preparation, health conditions, and reduced indoor air pollution.

\subsection{Case Study 3: Community Based Jatropha in Bati Woreda, Ethiopia}

Implementation: In Bati, the jatropha plant has been known to the local smallholder farmers since 1970 for its vital functions as a "hedge or living fence" and as a source of household energy and income [56]. Moreover, a new community based jatropha planation on "degraded" communal land was initiated and implemented by the organization for Rehabilitation and Development of Amhara and Woreda's office of Agriculture and Rural Development in 2008 [57] to generate biodiesel and to rehabilitate "degraded" land. A cooperative of about 300 farmers was organized, and began cultivating jatropha on "degraded" land; so far, they have cultivated it on 28,000hectares [57].

Description of technologies or products and services: Jatropha seed is utilized directly for cooking and lighting purposes. However, it can also be processed into biodiesel. Both can substitute for charcoal, fuelwood, and fossil fuels, and, thus alleviate energy expenditure, which is a significant financial burden to the households [58]. The annual expenditure on energy for a typical household in Bati was estimated to be US\$370, or $18.5 \%$ of the household's budget [58]. Moreover, the substitution of traditional energy with jatropha seeds and oil can improve household health, provide clean lighting for children to read and for women to perform domestic chores after daylight, and reduce labor use for biomass collection. Although jatropha seeds have been used as one of their energy options for four decades, it has not led to residential energy transition because jatropha harvested from the "hedge or living fence" was not sufficient to support energy transition [58], and farmers need to plant more jatropha on crop land, which is a justification for the cultivation of jatropha in communal areas. Despite a threefold increase in jatropha price over the period 2009-2012, farmers have not benefited economically [58].

Barriers and enablers: The main barriers identified are such as: "low jatropha yields, poor market linkages, and lack of financial and technical support" [57]. Low jatropha yield relates to the quality of land, but also water availability is inevitably a key factor. In Bati, jatropha was preferred to a tree plantation on degraded communal land because of its resistance to drought stresses, being poisonous for animals to browse, and its greater accessibility [56]. However, drought stress was found to be an underlying factor for the failure of large-scale biofuel projects in Ethiopia [58]. Little attention has been given to biofuel value chain development, as emphasis was given only to the cultivation of jatropha [57]. Although a biodiesel processor factory was installed in Kombolcha, near the project site, due to financial and technical barriers the factory was not functional [56]. In Bati, there are stoves and lamps fueled by crushed jatropha seeds or oil [56]. But the jatropha oil cookers were not utilized satisfactorily due to the fact that a majority of households were not able to afford them [57]. It was suggested that to tackle the barriers and enable the realization of economic and energy transition benefits, policy should emphasize farmers, local jatropha seed processors, and the creation of stable markets, training, and establishing professional biofuel workers [58].

WEF Nexus linkages: The Bati project was initiated not only for increased biofuel production, but, as discussed above, to enable the rehabilitation of gullies, soil and water conservation, and for 
the purpose of afforestation [58], thus creating synergies for improved soil and water retention, and reduced land degradation. Jatropha seeds and biodiesel substitution for biomass and fossil fuel has the potential to contribute to energy transition both in domestic use and the transportation sector. This can help reduce greenhouse gas emissions. The financial savings from energy substitution in terms of reduced energy expenditures can be used for buying food, and liberated time can be used for more food production. Moreover, jatropha by-products were used for the production of value added products (for example, fertilizer and biogas), which contribute to improved food and energy security. The reduced deforestation and the enhanced water and soil conservation created a win-win outcome for tackling reservoir siltation, and enhanced hydropower generation downstream.

\subsection{Case Study 4: Biomass Gasifier-Based Mini Grid in Garkha Village, Bihar, India}

Implementation: Garkha is a village located in the Bihar province of India, comprising 1465 families [59]. Due to highly unreliable electricity from the grid, villagers were earlier dependent on diesel generators. In 2006, Saran Renewable Energy (SRE) installed a biomass gasifier power plant in the village that now provides power to around 1000 households and businesses [60] at a cheaper price compared to existing diesel power plants. Sesbania (a woody shrub), which is grown in the water-clogged wastelands of the village, has been chosen as feedstock for the plant, providing sustainability to the power plant and additional farm income.

Description of technologies or products and services: The project utilizes a biomass gasifier and gas engines, designed to supply $128 \mathrm{KW}$ of electric power. Biomass gasifiers are a promising decentralized electricity technology, as they are available in a variety of small sizes, are dispatchable [61], can utilize a variety of biomass residues as feedstocks, and can generate additional income for the rural households who can contribute feed stock to a plant [62]. The cost of the entire power plant was INR 8,300,000 $(140,000$ USD at 1 USD= 60 INRs), with a majority of the expenditure invested by SRE and $25 \%$ secured as a bank loan. SRE incentivizes farmers to grow Sesbania in their fields, which otherwise remains waterlogged and barren during the summer-monsoon season. While this gives sustainable raw material supply to the gasifier, it also generates income (USD 80-120 per hectare) for the farmers. The plant charges INR 7.5/kWh (0.125 USD/kWh) per unit compared to INR 12-16/kWh (0.2-0.25 USD/kWh) with diesel mini grids.

Barriers and enablers: The concept of a biomass gasifier has been catching up in the last few years [63], however, there are several barriers which impede the widespread diffusion of such initiatives. One such barrier is their high initial costs [64], and the problem is aggravated with the unwillingness of banks to finance such technologies in rural areas. Another challenge is its competition with a highly subsidized electricity grid. The guaranteed purchase of surplus power by an electricity grid could have been an opportunity for such initiatives, but power evacuation is a challenge in rural areas. The sustainable supply of feedstock is another challenge [62,65].

WEF Nexus linkages: The Garkha project has significant linkages with the WEF Nexus. As reported by Ministry of New and Renewable Energy [60], the plant has been providing reliable power to around 10 water pumps in the village at half the price they were paying earlier (through diesel power), which has a direct positive impact on food production in the village. With this electricity facility, farmers are also able to remove water from their waterlogged fields and use it for farm production. With the reliable power, medical centers are now giving good health services, which can have direct consequences on the productivity of households. Sesbania has a property of fixing nitrogen in the soil, which decreases the requirements for fertilizers. Another possible spillover effect of the project could be a clean cooking solution for villagers, as one of the residues of a gasifier plant is the char, which can be developed into charcoal briquettes to be used by village households as clean cooking fuel. This can save a significant amount of household time in cooking fuel collection. The generated power will also help in pumping drinking water from greater depths, which avoids wells with shallow depths that have more chances for contamination, impacting the health and 
productivities of households. With reliable power in the village, local businesses will be encouraged and this will boost local employment.

\subsection{Case Study 5: Micro-Hydro Plant in Siklesh Village, Nepal}

Implementation: With the initiation of the Annapurna Conservation Area Project (ACAP), a micro-hydro plant (MHP) with a maximum output power of $100 \mathrm{~kW}$ was built in 1994 in Siklesh village to provide electricity to 346 households [66].

Description of technologies or products and services: With the construction of the MHP, the villagers obtained access to electricity for a variety of domestic and productive uses (such as night time lighting, and the operation of a mill). The MHP has also allowed the establishment of communication networks such as radio, television, and phones.

Barriers and enablers: Even though the clear switching from kerosene to electricity for lighting has been observed, the generated electricity was not able to replace fuelwood for cooking. Apart from the establishment of agro-processing mills, no other significant impact on increasing agricultural productivity has been observed. No motivation among elderly persons to follow modern practices of agriculture by linking to an MHP has been reported. As a result, about half of the cultivated lands was abandoned. In fact, the issue is quite common to most of the MHPs in Nepal, where the average load factor is only limited to $25 \%$ to $30 \%$, and hence these plants are commercially not viable [67]. With only development motives, the MPHs are being promoted by heavy subsidies of $60-80 \%$ of the total cost by aid groups [68].In the Nepalese context, despite the hasty development of MHPs in many rural areas, the linkage of energy with end-use applications for both cooking/heating and income generating activities is extremely poor; consequently, the potential contribution to the WEF Nexus has not been fully realized in practice. The foremost reason is associated with the provision of subsidies on MHPs only for the remote and inaccessible areas where no national grid exists. Hence, because of a lack of infrastructure and market opportunities in those areas, the challenges are there to utilize optimally the available electricity.

WEF Nexus linkages: Nevertheless, with the introduction of MHPs, some contributions to WEF Nexus have also been observed. For instance, the electricity during evenings has significant benefits in terms of the preparation and consumption of food because of the provision of better-quality lighting as compared to kerosene lanterns. Because of the higher luminous flux in the electric light, the conduct of kitchen activities has become quite convenient. Similarly, with the establishment of modern agricultural processing mills, the villagers have been able to engage their saved time on agricultural activities. The further potential of MHPs has been observed to positively contribute to the WEF Nexus' synergies by boosting the load factor with the intervention of water pumping for irrigation for higher food production.

\section{Discussion}

This paper evaluated the successes and failures of DES in developing countries through the lens of the WEF Nexus framework. We also investigated the contributions of DES to energy transition in remote villages in several developing countries in order to better understand how DES interact with and enable the realization of the synergies of the WEF Nexus. Table 1 summarizes the linkages of DES with the WEF Nexus assumed in the literature for each studied case, and provides our evaluations of the actual extent of these linkages through empirical observations. Table 1 shows that the assumed linkages did not materialize as expected in all of the cases due to the various specific reasons explained earlier in the case studies. The results indicate that DES initiatives did not result in complete energy transitions, as the target communities and households still relied on multiple energy sources due to a number of barriers to the adoption of DES. Nevertheless, the DES initiatives played an important role in improving energy access, and have shown potential to contribute to sustainable rural development and improve household and community wellbeing through enhanced food security, income, health, empowerment of women, and resource conservation. 
Table 1. Major linkages of Decentralized Energy Services (DES) within the Water-Energy-Food (WEF) Nexus in the studied cases.

\begin{tabular}{|c|c|c|c|c|}
\hline Case Study & Description & Assumed Linkages to WEF & Actually Observed Linkages to WEF & Sources \\
\hline $\begin{array}{l}\text { Household-based biogas } \\
\text { project, Chunfeng, China }\end{array}$ & $\begin{array}{l}\text { - Biogas digesterfor cooking } \\
\text { and lighting } \\
\text { Was implemented by } \\
136 \text { households }\end{array}$ & $\begin{array}{l}\text { - } \quad \text { reduces water pollution caused by discarded } \\
\text { pig dung and discharge of sewage } \\
\text { provides organic fertilizer for } \\
\text { agricultural production } \\
\text { frees the households from biomass collection } \\
\text { for food production }\end{array}$ & $\begin{array}{l}\text { - } \quad \text { Significantly reduced water pollution } \\
\text { - } \quad \text { No significant effect } \\
\quad \text { significant effect }\end{array}$ & [49] \\
\hline $\begin{array}{l}\text { Improved cooking stove } \\
\text { (ICS), Ecuador }\end{array}$ & $\begin{array}{l}\text { Improved biomass cook stoves for } \\
\text { cooking implemented in } 800 \\
\text { isolated rural households by } 2010\end{array}$ & $\begin{array}{l}\text { - Reduces wood consumption and deforestation } \\
\text { to enhance water regulation } \\
\text { improves cooking conditions and } \\
\text { - food preparation } \\
\text { - } \quad \text { improves quality of life } \\
\text { improves energy security }\end{array}$ & $\begin{array}{l}\text { - Significantly reduced wood consumption. } \\
\text { Improvement on water regulation needs } \\
\text { further research } \\
\text { - Significantly improved } \\
\text { Significantly improved quality of life, especially for } \\
\text { woman and children. Also, household living conditions } \\
\text { wereameliorated through cleaner and } \\
\text { improved kitchens } \\
\text { Only partly achieved. Though wood consumption was } \\
\text { reduced, ICS cannot be used for cooking in high } \\
\text { demand events (communal gatherings),and the } \\
\text { expensive and not always available Liquid Petroleum } \\
\text { Gas (LGP) is still needed }\end{array}$ & [55] \\
\hline $\begin{array}{c}\text { Biomass Gasifier,Garkha, } \\
\text { Bihar, India }\end{array}$ & $\begin{array}{l}\text { - Biomass gasifier run from the } \\
\text { Sesbania feedstock grown on the } \\
\text { waste lands } \\
\text { Provides electricity for domestic } \\
\text { and agricultural purposes }\end{array}$ & $\begin{array}{l}\text { - } \quad \text { income augmentation of local farmers } \\
\text { - } \quad \text { eliable irrigation and domestic } \\
\text { - } \quad \text { tackling wapply } \\
\text { - } \quad \text { facilitating better health and education } \\
\text { local employment }\end{array}$ & - All assumed linkages were also actually observed & [60] \\
\hline $\begin{array}{l}\text { Micro-hydro, } \\
\text { Siklesh,Nepal }\end{array}$ & $\begin{array}{l}\text { - } 100 \mathrm{~kW} \text { micro-hydrofor } \\
346 \text { households } \\
\text { - Provides electricity for lighting } \\
\text { and agro-processing. }\end{array}$ & $\begin{array}{l}\text { - better lighting has positive impact on } \\
\text { preparation and consumption of food } \\
\text { saves labor time because of the introduction of } \\
\text { modern agricultural facilities }\end{array}$ & $\begin{array}{l}\text { - } \quad \text { Had a significant effect } \\
\text { - }\end{array}$ & [66] \\
\hline
\end{tabular}




\section{Conclusions}

All in all, the case studies indicated that DES have positively contributed to household and community livelihoods, and are an integral component of the WEF Nexus.

The case studies identified a number of critical challenges that need to be addressed to improve the adoption of DES. Most often, DES initiatives focus on the installation of technologies, but many projects face ex post problems related to technical maintenance and the costs of operation and management, as well as coordination problems. The analysis also indicated that policies should consider local social, institutional, economic, environmental, and technological aspects, and the skills of the households and other actors in the DES value chains, to enable the initiatives to sustain themselves without external assistance, and gradually transform themselves into self-financing businesses. Therefore, DES intervention measures should target the building capacity of participants and stakeholders. We also recommend further quantitative studies to more specifically estimate the level of impacts and explore the feedbacks, synergies, and trade-offs of DES within the WEF Nexus framework.

Acknowledgments: The authors thank the German Federal Ministry for Economic Cooperation and Development (BMZ) and the GIZ-BEAF program (Project Number: 14.1432.5-001.00) for financially supporting this research.

Author Contributions: D.D.G. and A.M. conceived the paper; D.D.G., J.J., N.A., C.Q., and V.G. collected the case study data and elaborated the individual case studies. D.D.G. coordinated the writing process. All authors wrote the paper.

Conflicts of Interest: The authors declare no conflict of interest. The founding sponsors had no role in the design of the study; in the collection, analyses, or interpretation of data; in the writing of the manuscript, and in the decision to publish the results.

\section{References}

1. IEA. Energy for All: Financing Access for the Poor. Special Early Excerpt of the World Energy Outlook 2011. World Energy Outlook 2011, 52. Available online: http://www.worldenergyoutlook.org/media/ weowebsite/2011/weo2011_energy_for_all.pdf (accessed on 20 August 2016).

2. Modi, V.; McDade, S.; Lallement, D.; Saghir, J. Energy Services for the Millennium Development Goals. In Energy Sector Management Assistance Programme; United Nations Development Programme, UN Millennium Project and World Bank: Washington, DC, USA, 2005.

3. IEA. People Relying on Traditional Use of Biomass for Cooking in 2011 IEA, World Energy Outlook, 2013. Available online: http:/ / www.worldenergyoutlook.org/resources (accessed on 15 July 2015).

4. Guta, D. Effect of fuelwood scarcity and socio-economic factors on household biobased energy use and energy substitution in rural Ethiopia. Energy Policy 2014, 75, 217-227. [CrossRef]

5. Mirzabaev, A.; Guta, D.; Goedecke, J.; Gaur, V.; Börner, J.; Virchow, D.; Denich, M.; von Braun, J. Bioenergy, food security and poverty reduction: Trade-offs and synergies along the water-energy-food security nexus. Water Int. 2015, 40, 772-790. [CrossRef]

6. Rasul, G. Food, water, and energy security in South Asia: A nexus perspective from the Hindu Kush Himalayan region. Environ. Sci. Policy 2014, 39, 35-48. [CrossRef]

7. Van Els, R.H.; de Souza Vianna, J.N.; Brasil, A.C.P. The Brazilian experience of rural electrification in the Amazon with decentralized generation-The need to change the paradigm from electrification to development. Renew. Sustain. Energy Rev. 2012, 16, 1450-1461. [CrossRef]

8. Nieuwenhout, F.D.J.; van Dijk, A.; Lasschuit, P.E.; van Roekel, G.; van Dijk, V.A.P.; Hirsch, D.; Wade, H. Experience with solar home systems in developing countries: A review. Prog. Photovolt. Res. Appl. 2001, 9 , 455-474. [CrossRef]

9. Rehfuess, E.; Mehta, S.; Prüss-Üstün, A. Assessing household solid fuel use: Multiple implications for the Millennium Development Goals. Environ. Health Perspect. 2005, 114, 373-378. [CrossRef]

10. Mainali, B.; Pachauri, S.; Rao, N.; Silveira, S. Assessing rural energy sustainability in developing countries. Energy Sustain. Dev. 2014, 19, 15-28. [CrossRef]

11. Schäfer, M.; Kebir, N.; Neumann, K. Research needs for meeting the challenge of decentralized energy supply in developing countries. Energy Sustain. Dev. 2011, 15, 324-329. [CrossRef] 
12. Hoff, H. Understanding the Nexus. In Proceedings of the Bonn 2011 Conference: The Water, Energy and Food Security Nexus, Bonn, Germany, 16-18 November 2011; Stockholm Environment Institute: Stockholm, Sweden, 2011.

13. Von Braun, J. Bio-economy-Science and technology policy for agricultural development and food security. In Proceedings of the Festschrift Seminar in Honor of Per Pinstrup-Andersen on "New Directions in the Fight against Hunger and Malnutrition", Ithaca, NY, USA, 13 December 2013.

14. Flammini, A.; Puri, M.; Pluschke, L.; Dubois, O. Walking the Nexus Talk: Assessing the Water-Energy-Food Nexus in the Context of the Sustainable Energy for All Initiative. Available online: http://www.fao.org/3/ a-i3959e.pdf (accessed on 5 September 2014).

15. Terrapon-Pfaff, J.; Dienst, C.; König, J.; Ortiz, W. A cross-sectional review: Impacts and sustainability of small-scale renewable energy projects in developing countries. Renew. Sustain. Energy Rev. 2014, 40, 1-10. [CrossRef]

16. Villamayor-Tomas, S.; Grundmann, P.; Epstein, G.; Evans, T.; Kimmich, C. The water-energy-food security nexus through the lenses of the value chain and the Institutional Analysis and Development frameworks. Water Alternat. 2015, 8, 735-755.

17. Ringler, C.; Bhaduri, A.; Lawford, R. The nexus across water, energy, land and food (WELF): Potential for improved resource use efficiency? Curr. Opin. Environ. Sustain. 2013, 5, 617-624. [CrossRef]

18. Khan, S.; Hanjra, M. Footprints of water and energy inputs in food production-Global perspectives. Food Policy 2009, 34, 130-140. [CrossRef]

19. Schäfer, A.; Hughes, G.; Richards, B. Renewable energy powered membrane technology: A leapfrog approach to rural water treatment in developing countries? Renew. Sustain. Energy Rev. 2014, 40, 542-556. [CrossRef]

20. Hanjra, M.; Qureshi, E. Global water crisis and future food security in an era of climate change. Food Policy 2010, 35, 365-377. [CrossRef]

21. World Economic Forum. Accelerating Successful Smart Grid Pilots; World Economic Forum: Cologny/Geneva, Switzerland, 2010.

22. Patanothai, A.; Nansaior, A.; Rambo, A.T.; Simaraks, S. Climbing the energy ladder or diversifying energy sources? The continuing importance of household use of biomass energy in urbanizing communities in Northeast Thailand. Biomass Bioenergy 2011, 35, 4180-4188.

23. Barnes, D.F.; Floor, W.M. Rural Energy in Developing Countries: A challenge for Economic development. Annu. Rev. Energy Environ. 2016, 21, 497-530. [CrossRef]

24. Hosier, R.H.; Dowd, J. Household fuel choice in Zimbabwe: An empirical test of the energy ladderhypothesis. Res. Energy 1987, 9, 347-361. [CrossRef]

25. Leach, G. The energy transition. Energy Policy 1992, 20, 116-123. [CrossRef]

26. Guta, D. Application of an almost ideal demand system (AIDS) to Ethiopian rural residential energy use: Panel data evidence. Energy Policy 2012, 50, 528-539. [CrossRef]

27. Heltberg, R. Fuel switching: Evidence from eight developing countries. Energy Econ. 2004, 26, 869-887. [CrossRef]

28. Masera, O.R.; Navia, J. Fuel switching or multiple cooking fuels? Understanding inter-fuel substitution patterns in rural Mexican households. Biomass Bioenergy 1997, 12, 347-361. [CrossRef]

29. Murphy, T.J. Making the energy transition in rural East Africa: Is leapfrogging an alternative? Technol. Forecast. Soc. Chang. 2001, 68, 173-193. [CrossRef]

30. Marcotullio, P.J.; Schulz, N.B. Comparison of energy transitions in the United States and developing and industrializing economies. World Dev. 2007, 35, 1650-1683. [CrossRef]

31. Cherni, J.; Dyner, I.; Henao, F.; Jaramillo, P.; Smith, R.; Font, R. Energy supply for sustainable rural livelihoods. A multi-criteria decision-support system. Energy Policy 2007, 35, 1493-1504. [CrossRef]

32. Wirth, S. Communities matter: Institutional preconditions for community renewable energy. Energy Policy 2014, 70, 236-246. [CrossRef]

33. Gollwitzer, L. Community-Based Micro Grids: A Common Property Resource Problem; STEPS Working Paper 68; STEPS Center: Brighton, UK, 2014.

34. Holland, R.; Perera, L.; Sanchez, T.; Wilkinson, R. Decentralized Rural Electrification: Critical Success Factors and Experiences of an NGO. Refocus 2001, 2, 28-31. [CrossRef]

35. Pansera, M. Renewable energy for rural areas of Bolivia. Renew. Sustain. Energy Rev. 2012, 16, 6694-6704. [CrossRef] 
36. Malhotra, P. Management of community-based energy interventions in rural areas of India: Issues and perspectives. Sustain. Dev. 2006, 14, 33-45. [CrossRef]

37. Gómez, M.F.; Sanches-Pereira, A.; Silveira, S. Technology for social inclusion: The case of electricity access in the Brazilian Amazon. J. Sustain. Dev. Energy Water Environ. Syst. 2013, 1, 237-259. [CrossRef]

38. Haider, H. Community-Based Approaches to Peacebuilding in Conflict-Affected and Fragile Contexts: Issue Paper; University of Birmingham: Birmingham, UK, 2009.

39. Oteman, M.; Wiering, M.; Helderman, J. The institutional space of community initiatives for renewable energy: A comparative case study of the Netherlands, Germany and Denmark. Energy Sustain. Soc. 2014, 4, 11. [CrossRef]

40. Sapkota, A.; Lu, Z.; Yangm, H.; Wang, J. Role of renewable energy technologies in rural communities' adaptation to climate change in Nepal. Renew. Energy 2014, 68, 793-800. [CrossRef]

41. Pang, M.; Zhang, L.; Ulgiati, S.; Wang, C. Ecological impacts of small hydropower in China: Insights from an emergy analysis of a case plant. Energy Policy 2015, 76, 112-122. [CrossRef]

42. Kaundinya, D.P.; Balachandra, P.; Ravindranath, N.H. Grid-connected versus stand-alone energy systems for decentralized power-A review of literature. Renew. Sustain. Energy Rev. 2009, 13, 2041-2050. [CrossRef]

43. Herran, D.; Nakata, T. Design of decentralized energy systems for rural electrification in developing countries considering regional disparity. Appl. Energy 2012, 91, 130-145. [CrossRef]

44. Lahimer, A.; Alghoul, M.; Yousif, F.; Razykov, T.; Amin, T.; Sopian, K. Research and development aspects on decentralized electrification options for rural household. Renew. Sustain. Energy Rev. 2013, 24, 314-324. [CrossRef]

45. Rolland, S.; Glania, G. Hybrid Mini-Grids for Rural Electrification: Lessons Learned; Alliance for Rural Electrification (ARE): Brussels, Belgium, 2011.

46. Raha, D.; Mahanta, P.; Clarke, M. The implementation of decentralised biogas plants in Assam, NE India: The impact and effectiveness of the National Biogas and Manure Management Programme. Energy Policy 2014, 68, 80-91. [CrossRef]

47. Ahlborg, H.; Hammar, L. Drivers and barriers to rural electrification in Tanzania and Mozambique-grid-extension, off-grid, and renewable energy technologies. Renew. Energy 2014, 61, 117-124. [CrossRef]

48. Yin, R.K. Case Study Research: Design and Methods, 3rd ed.; Sage: Thousand Oaks, CA, USA, 2003.

49. Qin, H.; Quan, J. What Does the Story of Chunfeng Village Tell Us? Available online: http:/ / dangjian.people. com.cn/n/2014/0717/c368894-25292864.html (accessed on 17 July 2014).

50. Chinese People's Political Consultative Conference (CPPCC). Viewpoints on Promoting the Execution of the 'Prosperous Eco-farmyards' Plan (in Chinese). Draft Proposal nr.0003. In Proceedings of the Second Session of the Tenth National Committee of the CPPCC, Beijing, China, 12 March 2004.

51. Chen, Y.; Yang, G.; Sweeney, S.; Feng, Y. Household biogas use in rural China: A study of opportunities and constraints. Renew. Sustain. Energy Rev. 2010, 14, 545-549. [CrossRef]

52. He, G.Z.; Bluemling, B.; Mol, A.P.J.; Zhang, L.; Lu, Y.L. Comparing centralized and decentralized bio-energy systems in rural China. Energy Policy 2013, 63, 34-43. [CrossRef]

53. Zhang, F.; Watanabe, M.; Lin, T.; Delaquil, P.; Wang, H.; Alipalo, H. Rural Biomass Energy 2020: Cleaner Energy, Better Environment, Higher Rural Income, People's Republic of China; Asian Development Bank: Mandaluyong, Philippines, 2010.

54. Gosens, J.; Lu, Y.L.; He, G.Z.; Bluemling, B.; Beckers, T.A.M. Sustainability effects of household-scale biogas in rural China. Energy Policy 2013, 54, 273-287. [CrossRef]

55. Zevallos, H.; Paño, E.; Cruz, I.; Calderon, G. Adopcion de la Tecnologia de Cocinasmejoradas y Empoderamiento para la Mejora de Calidad de vida en Comunidades Rurales; ADRA Ecuador: Quito, Ecuador, 2013. Available online: https://issuu.com/aeaandina/docs/aea_sistematizaci_n_proyecto_cocin (accessed on 30 June 2017).

56. Bach, S. Potentials and Limitations of Jatropha Curcas as a Multipurpose Crop for Sustainable Energy Supply and Soil and Water Conservation. A Case Study in Bati, Ethiopia, Using the WOCAT Approach. Master's Thesis, University of Bern, Bern, Switzerland, 2012.

57. Amsalu, A.; Teklu, N.; Kassa, M.; Workagegnehu, H. Community-Based Biofuel Development and Environmental Rehabilitation in Ethiopia: The Case of Bati in Amhara Region; PHE Ethiopia Consortium: Addis Ababa, Ethiopia, 2013.

58. Portner, B.; Ehrensperger, A.; Nezir, Z.; Breu, T.; Hurni, H. Biofuels for a greener econmy? Insights from jatropha production in Northreastern Ethiopia. Sustainability 2014, 6, 6188-6202. [CrossRef] 
59. Census of India 2011. Available online: http://www.censusindia.gov.in/2011census/dchb/1017_PART_B_ DCHB_SARAN.pdf (accessed on 27 June 2017).

60. MNRE (Ministry of New and Renewable Energy), India. Compendium titled Empowering India the RE way: inspiring success stories, released on 9th October 2012 at Vigyan Bhawan, New Delhi. Available online: http:/ / mnre.gov.in/file-manager/UserFiles/compendium.pdf (accessed on 27 June 2017).

61. Department for International Development (DFID). Low Carbon Mini Grids. "Identifying the Gaps and Building the Evidence Base on Low Carbon Mini Grids"; DFID: London, UK, 2013.

62. Yadoo, A.; Cruickshank, H. The role for low carbon electrification technologies in poverty reduction and climate change strategies: A focus on renewable energy mini-grids with case studies in Nepal, Peru and Kenya. Energy Policy 2012, 42, 591-602. [CrossRef]

63. Palit, D.; Sarangi, G. Renewable Energy Based Mini-grids for Enhancing Electricity Access. In Proceedings of the International Conference and Utility Exhibition 2014 on Green Energy for Sustainable Development, Pattaya, Thailand, 19-21 March 2014.

64. Bhattacharya, S.; Cropper, M.L. Options for Energy Efficiency in India Barriers to Their Adoption. Discussion Paper-Resources for the Future. Available online: http://www.rff.org/files/sharepoint/WorkImages/ Download/RFF-DP-10-20.pdf (accessed on 23 June 2017).

65. Debajit, P.; Sovacool, B.K.; Cooper, C.; Zoppo, D.; Eidsness, J.; Crafton, M.; Johnson, K.; Clarke, S. The trials and tribulations of the Village Energy Security Programme (VESP) in India. Energy Policy 2013, 57. [CrossRef]

66. Gurung, A.; Ian, B.; Sang-Eun, O. Micro-hydropower: A promising decentralized renewable technology and its impact on rural livelihoods. Sci. Res. Essays 2011, 6, 1240-1248.

67. Sovacool, B.K.; Dhakal, S.; Gippner, O.; Bambawale, M. Electrification in the mountain Kingdom: The implications of the Nepal Power Development Project (NPDP). Energy Sustain. Dev. 2011, 15, 254-265. [CrossRef]

68. Fulford, D.; Mosley, P.; Gill, A. Field Report: Recommendations on the Use of Micro-Hydro Power in Rural Development. J. Int. Dev. 2000, 12, 975-983. [CrossRef]

(C) 2017 by the authors. Licensee MDPI, Basel, Switzerland. This article is an open access article distributed under the terms and conditions of the Creative Commons Attribution (CC BY) license (http:/ / creativecommons.org/licenses/by/4.0/). 